PREPARED FOR THE U.S. DEPARTMENT OF ENERGY, UNDER CONTRACT DE-AC02-76CH03073

PPPL-3697

PPPL-3697

UC-70

Tritium Removal from JET and TFTR

Tiles by a Scanning Laser

by

C.H. Skinner, N. Bekris, J.P. Coad, C.A. Gentile, and M. Glugla

May 2002

NM|

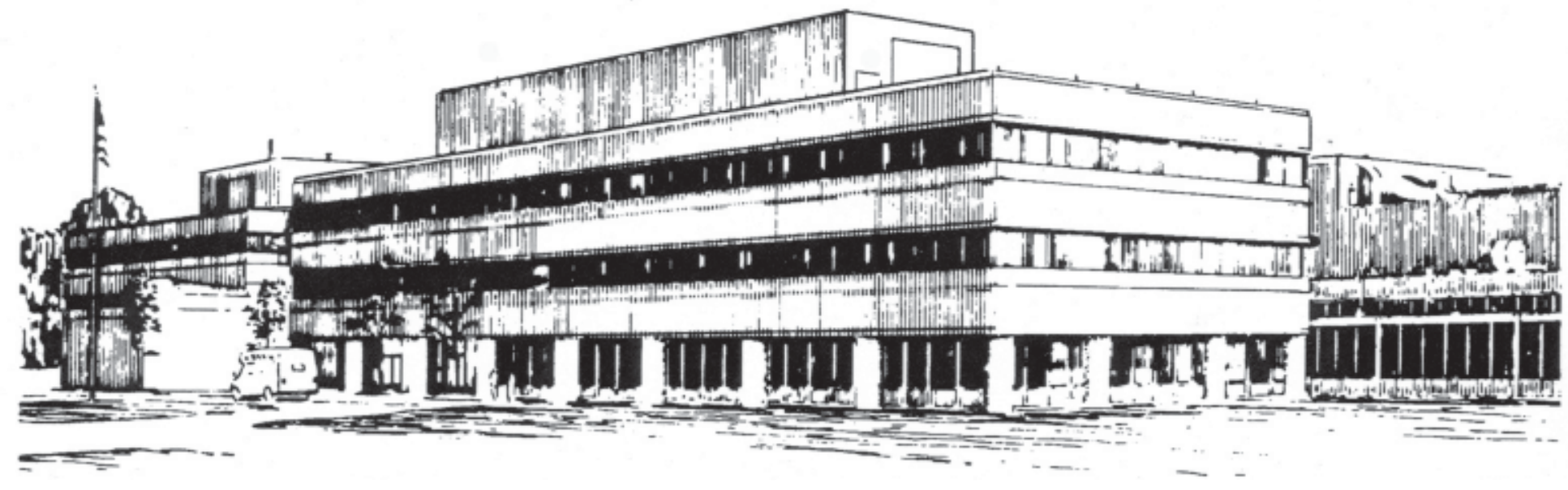

PRINCETON PLASMA PHYSICS LABORATORY PRINCETON UNIVERSITY, PRINCETON, NEW JERSEY 


\section{PPPL Reports Disclaimer}

This report was prepared as an account of work sponsored by an agency of the United States Government. Neither the United States Government nor any agency thereof, nor any of their employees, makes any warranty, express or implied, or assumes any legal liability or responsibility for the accuracy, completeness, or usefulness of any information, apparatus, product, or process disclosed, or represents that its use would not infringe privately owned rights. Reference herein to any specific commercial product, process, or service by trade name, trademark, manufacturer, or otherwise, does not necessarily constitute or imply its endorsement, recommendation, or favoring by the United States Government or any agency thereof. The views and opinions of authors expressed herein do not necessarily state or reflect those of the United States Government or any agency thereof.

\section{Availability}

This report is posted on the U.S. Department of Energy's Princeton Plasma Physics Laboratory Publications and Reports web site in Fiscal Year 2002. The home page for PPPL Reports and Publications is: http://www.pppl.gov/pub_report/

DOE and DOE Contractors can obtain copies of this report from:

U.S. Department of Energy

Office of Scientific and Technical Information

DOE Technical Information Services (DTIS)

P.O. Box 62

Oak Ridge, TN 37831

Telephone: (865) 576-8401

Fax: (865) 576-5728

Email: reports@adonis.osti.gov

This report is available to the general public from:

National Technical Information Service

U.S. Department of Commerce

5285 Port Royal Road

Springfield, VA 22161

Telephone: 1-800-553-6847 or

(703) 605-6000

Fax: (703) 321-8547

Internet: http://www.ntis.gov/ordering.htm 


\title{
Tritium removal from JET and TFTR tiles by a scanning laser
}

\author{
C. H. Skinner, N. Bekris ${ }^{\mathrm{a}}$, J. P. Coad ${ }^{\mathrm{b}}$, C. A. Gentile, M. Glugla ${ }^{\mathrm{a}}$. \\ Princeton Plasma Physics Laboratory, Princeton, New Jersey, 08543 USA. \\ ${ }^{a}$ Tritium Laboratory, Research Center Karlsruhe, Germany. \\ ${ }^{b}$ UKAEA Fusion, Culham, JET Joint Undertaking, Abingdon, Oxon, UK.
}

\begin{abstract}
:
Fast and efficient tritium removal is needed for future DT machines with carbon plasma facing components. A novel method for tritium release has been demonstrated on codeposited layers on tiles retrieved from the Tokamak Fusion Test Reactor (TFTR) and from the Joint European Torus (JET). A scanning continuous wave Nd laser beam was focused to $\approx 100 \mathrm{~W} / \mathrm{mm}^{2}$ and scanned at high speed over the codeposits, heating them to temperatures $\approx 2000{ }^{\circ} \mathrm{C}$ for about 10 $\mathrm{ms}$ in either air or argon atmospheres. Fiber optic coupling between the laser and scanner was implemented. Up to $87 \%$ of the codeposited tritium was thermally desorbed from the JET and TFTR samples. This technique appears to be a promising in-situ method for tritium removal in a next step DT device as it avoids oxidation, the associated deconditioning of the plasma facing surfaces and the expense of processing large quantities of tritium oxide.
\end{abstract}

Keywords: tritium removal, tritium codeposition, lasers, nuclear fusion.

\section{Introduction}

Tritium removal from codeposited layers is a critical issue for next-step devices with carbon plasma facing components[1,2]. While tritium removal has been demonstrated via glow discharges and air ventilation in TFTR[3,4] and JET[5], these methods are too slow for a nextstep device. Oxidative techniques for removing $\mathrm{H}$-isotopes have been used in TEXTOR[6], however in a next step device these will decondition the plasma facing surfaces, risk collateral damage of in-vessel components and require a large investment in the tritium plant to process the resulting tritium oxide. Heating tritiated codeposits with a rapidly scanning laser beam in vacuum or an inert atmosphere was proposed as a convenient way to thermally desorb tritium 
without the deleterious effects of oxidation[7]. Recent tabletop experiments with a scanning $\mathrm{Nd}$ laser have demonstrated efficient removal of tritium from TFTR tiles[8]. Some aspects of implementation in a next step tokamak are discussed in ref. [9] and the thermal response of codeposits to high heat flux further explored in $[10,11]$. In this paper we extend laser detritiation to laboratory experiments on JET tile samples from the DTE1 campaign.

\section{Experimental setup}

The overall aim of these experiments was to gain experience with laser detritiation of JET codeposits and to find conditions of optimal laser intensity and duration for tritium release with minimal surface change. The experimental setup (Fig. 1) was fully reported in [8]. Briefly, a 325 $\mathrm{W}$ continuous wave $\mathrm{Nd}$ laser beam is steered by two orthogonal mirrors and focused inside a chamber containing a tile sample. The laser spot can be scanned over a field of $75 \times 75 \mathrm{~mm}$ with a velocity of up to $2 \mathrm{~m} / \mathrm{s}$. The spot trajectory is defined by programming the motion of the scan mirrors via a computer interface. Typically, a serpentine raster pattern with line spacing $0.5 \mathrm{~mm}$ is used to cover the tile surface. An area of $5 \mathrm{~cm}^{2} / \mathrm{s}$ or $2 \mathrm{~m}^{2} /$ hour can be scanned at a speed of $1 \mathrm{~m} / \mathrm{s}$. The laser spot is $1.6 \mathrm{~mm}$ diameter (FWHM), so a given location on the tile surface experiences first the fringe of the laser spot, then the center, then the fringe in successive passes. A pyrometer measures surface temperatures in the range $500-2300{ }^{\circ} \mathrm{C}$ with $0.3 \mathrm{~ms}$ time resolution, and averages over a $0.7 \mathrm{~mm}$ area on the tile surface. Previous work[8] has showed the presence of $\approx 0.1 \mathrm{~mm}$ 'hot spots' due to microstructure in the codeposit. Before and after laser irradiation the tile surface is photographed by a digital microscope to record any changes in the surface. Released tritium was circulated in a closed loop to an ion chamber that measured the tritium concentration. Results from TFTR tiles[8] showed a major fraction of the tritium was desorbed with minimal changes to the tile surface at a laser intensity of $80 \mathrm{~W} / \mathrm{mm}^{2}$ and heating duration 10-20 ms. The temperature rise of the TFTR codeposits was much higher than that of the manufactured tile material (e.g. $1770{ }^{\circ} \mathrm{C}$ cf. $1080{ }^{\circ} \mathrm{C}$ ) indicating a significantly lower thermal conductivity for the codeposits[10].

For tokamak applications it is advantageous to fiber optically couple the beam from an external laser to an in-vessel scanner. Fiber optic coupling of the laser to the scanner also smoothes any spatial inhomogeneities in the focal spot. In-situ laser detritiation is proposed for the poloidal 
limiter tiles inside the JET vessel during the 2004 shutdown when the vessel would contain air and both air and argon atmospheres were used in the laboratory experiments. For some of the laboratory experiments the laser beam was coupled to the scanner via an armor jacketed $5 \mathrm{~m}$ long, $600 \mu \mathrm{m}$ fused silica fiber with antireflection coatings on the fiber ends. The maximum power delivered to the tile sample was 257 watts. The complete spatial profile of the focal spot was measured at full laser power by scanning the beam over a 35-micron pinhole on gold plated copper disk placed at the same position as the tile samples. The transmitted light was measured with a PIN diode. The full width at half maximum was $1.6 \mathrm{~mm}$. Previous estimates of both the fiber coupled case and direct coupled case were made by measuring the mark made by a stationary spot on a tile and were $1.8 \mathrm{~mm}$ for the fiber optic case and $2 \mathrm{~mm}$ for the direct coupled case (slightly defocused). A comparison of the thermal response of TFTR cube KC17-1C-Z3 irradiated at an estimated $80 \mathrm{~W} / \mathrm{mm}^{2}$, scan speed $1 \mathrm{~m} / \mathrm{s}$ with direct coupling between the laser and scanner, to TFTR cube KB13-13E-Z2 irradiated at $93 \mathrm{~W} / \mathrm{mm}^{2}$, scan speed $1 \mathrm{~m} / \mathrm{s}$ with the new fiber optic coupling showed a temperature rise of $2017{ }^{\circ} \mathrm{C}$ with the fiber optic cf. $1682{ }^{\circ} \mathrm{C}$ and tritium release of $1.5 \mathrm{mCi} / \mathrm{cm}^{2} \mathrm{cf} .2 .3 \mathrm{mCi} / \mathrm{cm}^{2}$. These differences are within the variation experienced from different samples. In both these cases the codeposit appeared to be undisturbed with a small darkening in color.

\section{Laser scanning experiments.}

A total of seven samples from JET were irradiated by the laser. These were $2 \mathrm{~cm}$ diameter cylinders cut from carbon fiber composite divertor tiles and a graphite poloidal limiter tile. The samples were from the plasma facing side of the inner divertor vertical tile (IN3-cylinder 16), the bottom edge of this tile at the entrance to the louvers (IN3-15, (this area had very high tritium concentration)); the inner base divertor tile 4 (1BN4-8, 1BN4-9, 1BN4-10); the outboard base divertor tile (1BN7-15) and poloidal limiter 4B (PL4B7top-6). The plasma facing surface was typically divided into 4 zones that were irradiated separately at different laser power and scan speeds. The samples showed a wide variety of erosion and deposition conditions, even on the same sample and in some areas the deposited layer had flaked off. Tritium depth profiles[12] and surface analyses[13] for JET tiles have been reported previously. In comparison, the TFTR samples reported in [8] were from three tiles on the inner limiter, the codeposits were more homogeneous and without flaking.

C. H. Skinner page 4 


\subsection{Temperature response of JET samples}

The most conspicuous feature of response of the JET samples was the much higher temperature increase for codeposits compared to the bare tile material, as was the case for the TFTR samples. The peak temperature for the codeposited area on PL4B7top- 6 was $1790{ }^{\circ} \mathrm{C}$ compared to a much lower peak temperature of $1195^{\circ} \mathrm{C}$ on an adjacent 'bare' spot where the codeposit had flaked off (both scans $80 \mathrm{~W} / \mathrm{mm}^{2} @ 1 \mathrm{~m} / \mathrm{s}$ ). Generally tritium was released from both TFTR and JET samples at temperatures above $1500{ }^{\circ} \mathrm{C}$. A precise temperature threshold was difficult to identify since the temperature depended strongly on the surface topography, which varied across a single sample. Often the peak temperature of JET samples exceeded $2300{ }^{\circ} \mathrm{C}$, the upper limit of the pyrometer.

The temperature time history varied significantly with the surface morphology. Fig. 2 compares the response of two samples cut from the same inner base divertor tile and both exposed to similar laser power ( 80 and $\left.74 \mathrm{~W} / \mathrm{mm}^{2}\right)$ and scan speed of $1 \mathrm{~m} / \mathrm{s}$. 1BN4-8-4L is from an erosion area in the strike point region and shows a $5 \mathrm{~ms}$ duration temperature excursion to $1434 \mathrm{C}$. Sample 1BN4-9-z2.1 is $107 \mathrm{~mm}$ away but shadowed from plasma flux by tile 3 . The pyrometer viewed the deposit on the surface of 1BN4-9. The temperature rose to over $2300{ }^{\circ} \mathrm{C}$ (the limit for the pyrometer) and the duration of the temperature excursion was extended to approximately 30 ms. The deposit appears to be less thermally conductive and/or not in good thermal contact with the substrate. The dramatically different peak temperatures for the same heat flux illustrate the difficulty of deducing heat flux from measurements of surface temperature rise during ELMs in tokamaks[14].

\subsection{Tritium release}

The high surface temperatures readily released tritium from the deposited layers. The area of heavy deposition on the bottom edge of tile 3 (IN3-15) released $71 \mathrm{mCi} / \mathrm{cm}^{2}\left(2.4 \mathrm{GBq} / \mathrm{cm}^{2}\right)$. In contrast, the erosion area on the vertical plasma facing side of the same tile (IN3-16) released only $0.25 \mathrm{mCi} / \mathrm{cm}^{2}\left(9 \mathrm{MBq} / \mathrm{cm}^{2}\right)$. For deposition areas, repeating a laser scan yielded an additional $10-15 \%$ more tritium. While not a large amount, this is a significant fraction of the tritium remaining and so repeating a scan is worthwhile to maximize the detritiation efficiency. Tritium remaining in the deposited layer after the laser scan, was released by baking the sample 
in an air atmosphere. To do this the laser spot was defocused and remained stationary on the sample surface, which was heated to approximately $500 \mathrm{C}$. The residual tritium was released in 5-10 minutes. Fig. 3 shows all the results for JET and TFTR samples scanned under a variety of conditions. The detritiation efficiency (ratio of tritium released by the laser scan to the total released in the scan and bake) was high in the deposition regions where most of the tritium is located and reached $87 \%$ for PL4B7top-6.

The atmosphere inside the chamber is circulated continuously. It is clearly important to check for reabsorption, for example by isotope exchange with water on the interior chamber surface or reabsorption back into the graphite, that could hinder pumping tritium out of a next step device. Fig. 4 shows the tritium concentration after a laser scan in an argon and air atmosphere. After an initial transient there is very little reabsorption. The atmosphere inside JET during the shutdown is air, which is exchanged every hour. On this time scale nearly all of the tritium remained in gaseous form and could be pumped out. A second issue is the potential for tritium to be driven deeper into the tile by the laser heating. This would be unlikely on a millisecond time scale and we note that previous work showed that the tritium profiles in a JET tile was unchanged on heating to $460{ }^{\circ} \mathrm{C}$ for 1 hour[15].

The effect on the surface of the intense heat of the laser was small at the fast scan speeds used (as was the case for TFTR samples). The surface changes from a brownish hue to dark gray but the codeposit was still intact even though the surface temperature briefly exceeded $2300{ }^{\circ} \mathrm{C}$ (Fig. 5). Thick friable codeposits such as at the base edge of inner divertor tile 3 change appearance somewhat on laser scanning. Sample IN3-16 is of interest as a 'mixed material' - the surface has comparable $\mathrm{Be}$ and $\mathrm{C}$ concentrations[13]. Here the surface layer after laser exposure became a pattern of $100 \mu \mathrm{m}$ beads. This sample showed low tritium release $\left(0.25 \mathrm{mCi} / \mathrm{cm}^{2}, 9 \mathrm{MBq} / \mathrm{cm}^{2}\right)$ and unlike the other samples the tritium concentration rose slowly and continuously during the bake. Mixed material issues add significant uncertainty to predictions of the behavior of tokamak materials and more investigations using tokamak-generated materials are needed.

\section{Summary.}

Laser detritiation was able to release up to $87 \%$ of the tritium trapped in codeposits on JET tiles, similar to the results from TFTR samples. Fiber optic coupling between the laser and scanner 
was implemented and three samples were scanned in an air atmosphere to mimic the situation during the JET shutdown. The temperature rise and fraction of tritium released was reduced in erosion areas, but the tritium inventory in such areas is small. The sample-to-sample variability of the JET samples makes it difficult to make precise comparisons with the TFTR samples. For JET samples the temperature excursions on regions of heavy deposition often exceeded $2300{ }^{\circ} \mathrm{C}$ and showed a protracted 'ragged' character possibly indicating burn up of dust from a more friable codeposit and/or chemical reactions with oxides present in the tiles[11]. The experience to date has shown that this technique is very promising for the removal of tritium from next step devices and an engineering scale demonstration during the JET 2004 shutdown has been proposed.

\section{Acknowledgments}

We wish to acknowledge informative discussions with R. Causey, G. Federici, K. M. Young, and the dedicated work of the tritium group A. Carpe, G. Guttadora, S. Langish, and collaborators at PPPL. We thank J. Dong, A. Planetta and the PPPL health physics group for supporting these measurements. Financial support was provided by U.S. DOE Contract Nos. DEAC02-76CH0307 and by the EU within the European Fusion Program. 


\section{Figure Captions:}

Fig. 1 Experimental setup.

Fig. 2 Temperature response of a deposition region 1BN4-9-z2.1 (upper curve) and erosion region 1BN4-8-4L (lower curve) to two successive passes of the laser spot. The laser time history (measured separately) is shown dotted. The pyrometer operates in the region $500{ }^{\circ} \mathrm{C}-2300{ }^{\circ} \mathrm{C}$.

Fig. 3 Tritium released by laser scanning and the subsequent bake in air for samples from JET and TFTR. A variety of scan conditions were used, some not yet optimal. Non the less the results illustrate that the detritiation efficiency is high at the locations with the highest concentrations of tritium. The column labels from $1-7$ correspond to: JET:IN3-16, JET:1BN4-8, JET:1BN7-15, TFTR:KC22-6E, JET:1BN4-9, TFTR:KC22-6C, JET:PL4B-7top.

Fig. 4 Tritium concentration vs. time after laser scan in argon atmosphere (IN3-15-1c) and air (INB4-9-z2.1).

Fig. 5 Images of the tile surface of sample 1BN4-9 before (a) and after (b) two laser scans at 1 $\mathrm{m} / \mathrm{s}, 128 \mathrm{~W} / \mathrm{mm}^{2}$ in air, peak temperature $>2300 \mathrm{C}$; and PL4B7top-6 before (c) and after, (d) 3 laser scans at $1 \mathrm{~m} / \mathrm{s}, 80 \mathrm{~W} / \mathrm{mm}^{2}$ in argon, peak temperature $2082{ }^{\circ} \mathrm{C}$. Images (a) and (b) were taken at normal incidence, (c) and (d) at 45 degrees. Each image covers $9.6 \mathrm{~mm}$ in the horizontal direction. 


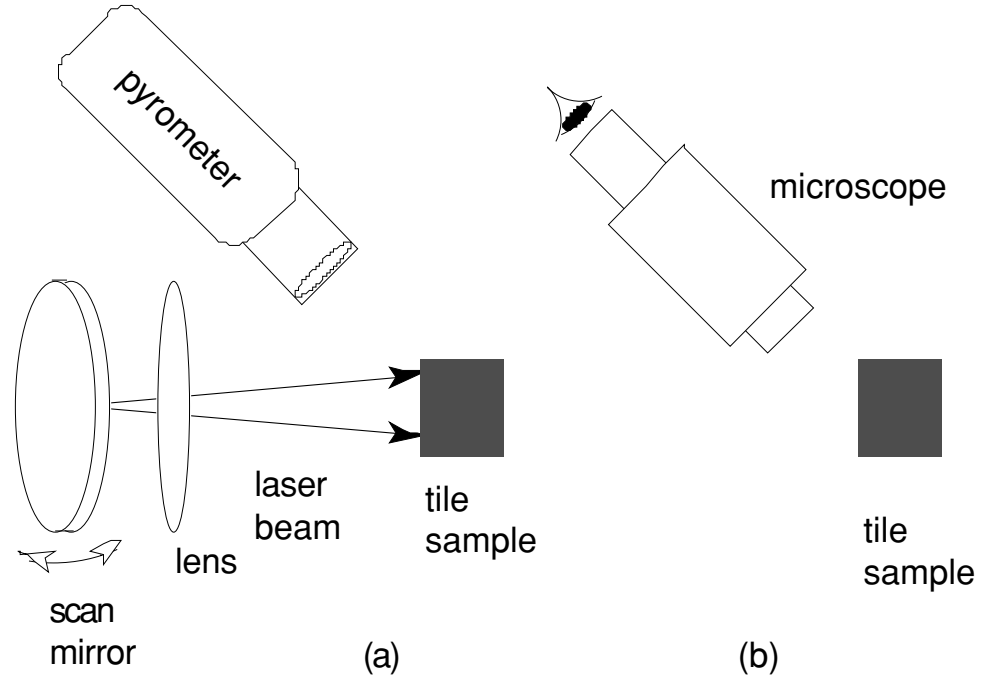

Fig. 1 Experimental setup. 


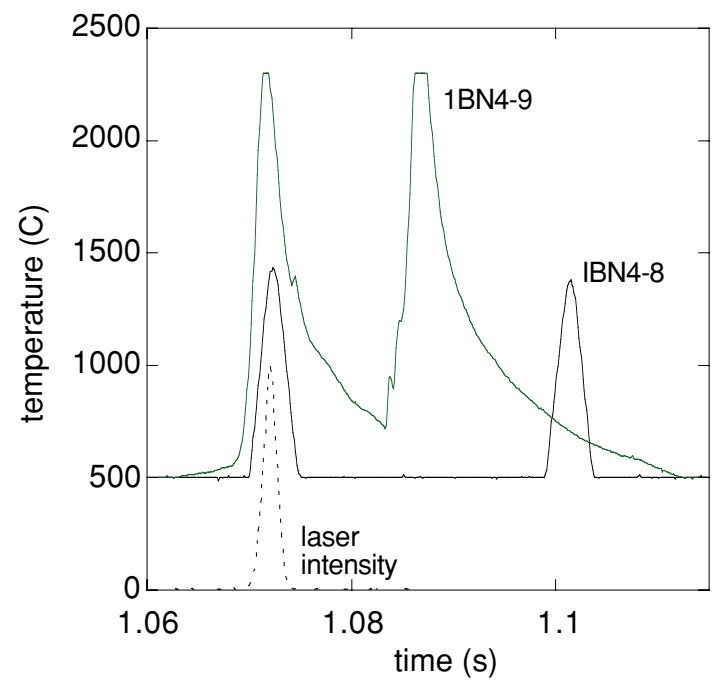

Fig. 2 Temperature response of a deposition region 1BN4-9-z2.1 (upper curve) and erosion region 1BN4-8-4L (lower curve) to two successive passes of the laser spot. The laser time history (measured separately) is shown dotted. The pyrometer operates in the region $500{ }^{\circ} \mathrm{C}-2300^{\circ} \mathrm{C}$. 


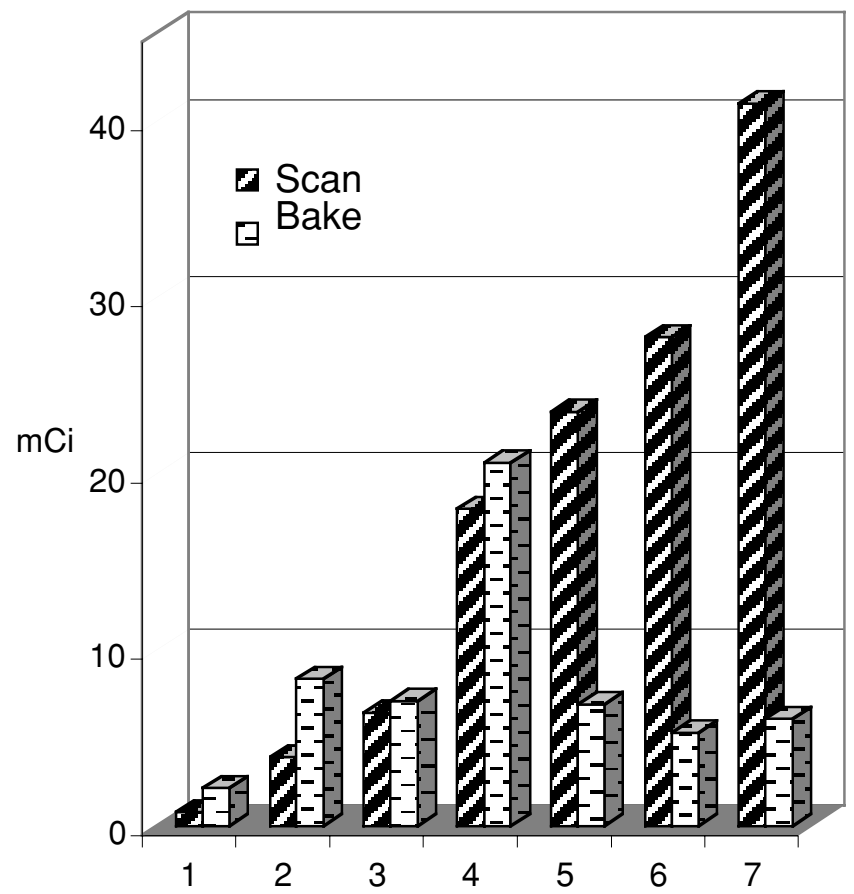

Fig. 3 Tritium released by laser scanning and the subsequent bake in air for samples from JET and TFTR. A variety of scan conditions were used, some not yet optimal. Non the less the results illustrate that the detritiation efficiency is high at the locations with the highest concentrations of tritium. The column labels from 1 - 7 correspond to: JET:IN3-16, JET:1BN4-8, JET:1BN7-15, TFTR:KC22-6E, JET:1BN4-9, TFTR:KC22-6C, JET:PL4B-7top. 


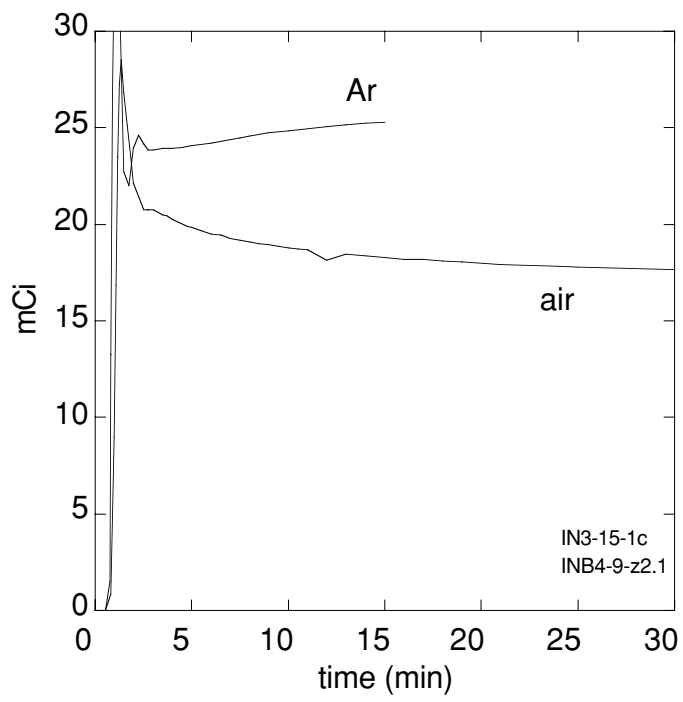

Fig. 4 Tritium concentration vs. time after laser scan in argon atmosphere (IN3-15-1c) and air (INB4-9-z2.1). 

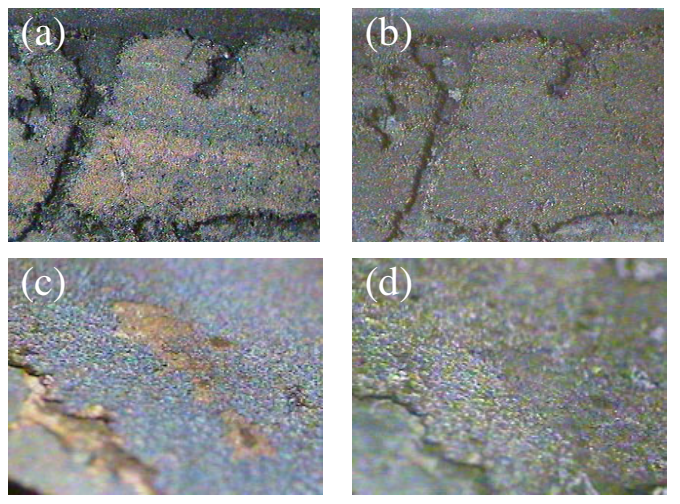

Fig. 5 Images of the tile surface of sample 1BN4-9 before (a) and after (b) two laser scans at 1 $\mathrm{m} / \mathrm{s}, 128 \mathrm{~W} / \mathrm{mm}^{2}$ in air, peak temperature > $2300 \mathrm{C}$; and PL4B7top-6 before (c) and after, (d) 3 laser scans at $1 \mathrm{~m} / \mathrm{s}, 80 \mathrm{~W} / \mathrm{mm}^{2}$ in argon, peak temperature $2082{ }^{\circ} \mathrm{C}$. Images (a) and (b) were taken at normal incidence, (c) and (d) at 45 degrees. Each image covers $9.6 \mathrm{~mm}$ in the horizontal direction. 


\section{References:}

[1] G. Federici et al., Nucl. Fus. 41 (2001) 1967.

[2] C. H. Skinner and G. Federici, Proceedings of the International Conference on Advanced Diagnostics for Magnetic and Interial Fusion, Varenna, Italy Sept. 3-7 ${ }^{\text {th }}, 2001$, Advanced Diagnostics for Magnetic and Inertial Fusion, P. Stott et al., eds., Kluwer Academic/Plenum, New York 2002.

[3] D. Mueller et al., J. Nucl. Mater., 241-243 (1997) 897.

[4] C. H. Skinner et al., $28^{\text {th }}$ EPS Conference on Controlled Fusion and Plasma Physics, Madeira, Portugal, 18-22 $2^{\text {nd }}$ June, 2001, Europhysics Conference Absracts, Vol. 25A (2001) 1621-1624

[5] P. Andrew et al., Fus. Eng. \& Des., 47 (1999) 233.

[6] V. Philipps, J. Nucl. Mater., 266-269 (1999) 386.

[7] C. H. Skinner, et al., Proceedings of the 17th IEEE/NPSS Symposium on Fusion Engineering, San Diego, October 6-10, 1997, vol. 1, pp.321-324, IEEE, Piscataway, NJ, USA (1998).

[8] C. H. Skinner et al., J. Nucl. Mater., 301 (2002) 98.

[9] C. H. Skinner, et al., Proceedings of the $6^{\text {th }}$ International Conference on Tritium Science and Technology, Tsukuba City, Ibaraki, Japan, Nov $11-16^{\text {th }}$ to be published in Fusion Science and Technology (2002).

[10] C. H. Skinner et al., Proceedings of the $19^{\text {th }}$ IEEE/NPSS Symposium on Fusion Engineering (SOFE) Atlantic City, N.J., Jan.22-25 ${ }^{\text {th }}$, 2002, IEEE, Piscataway, NJ, USA (2002)

[11] C. H. Skinner et al., Proceedings of the International Workshop on Hydrogen Isotopes in Fusion Reactor Materials, May 22-24, 2002, Tokyo, to be published in Physica Scripta.

[12] R.-D. Penzhorn et al., J. Nucl. Mater., 288 (2001) 170.

[13] J. P. Coad et al., J. Nucl. Mater., 290-293 (2001) 224.

[14] S. Clement et al., J. Nucl. Mater., 266-269 (1999) 285.

[15] R.-D. Penzhorn et al., Fus. Engin. \& Des. $56-57$ (2001) 105. 


\section{External Distribution}

Plasma Research Laboratory, Australian National University, Australia

Professor I.R. J ones, Flinders University, Australia

Professor J oão Canalle, Instituto de Fisica DEQ/IF - UERJ , Brazil

Mr. Gerson O. Ludwig, Instituto Nacional de Pesquisas, Brazil

Dr. P.H. Sakanaka, Instituto Fisica, Brazil

The Librarian, Culham Laboratory, England

Library, R61, Rutherford Appleton Laboratory, England

Mrs. S.A. Hutchinson, JET Library, England

Professor M.N. Bussac, Ecole Polytechnique, France

Librarian, Max-Planck-Institut für Plasmaphysik, Germany

J olan Moldvai, Reports Library, MTA KFKI-ATKI, Hungary

Dr. P. Kaw, Institute for Plasma Research, India

Ms. P.J . Pathak, Librarian, Insitute for Plasma Research, India

Ms. Clelia De Palo, Associazione EURATOM-ENEA, I taly

Dr. G. Grosso, Instituto di Fisica del Plasma, Italy

Librarian, Naka Fusion Research Establishment, J AERI, J apan

Library, Plasma Physics Laboratory, Kyoto University, J apan

Research Information Center, National Institute for Fusion Science, J apan

Dr. O. Mitarai, Kyushu Tokai University, J apan

Library, Academia Sinica, Institute of Plasma Physics, People's Republic of China

Shih-Tung Tsai, Institute of Physics, Chinese Academy of Sciences, People's Republic of China

Dr. S. Mirnov, TRINITI, Troitsk, Russian Federation, Russia

Dr. V.S. Strelkov, Kurchatov Institute, Russian Federation, Russia

Professor Peter Lukac, Katedra Fyziky Plazmy MFF UK, Mlynska dolina F-2, Komenskeho Univerzita, SK-842 15 Bratislava, Slovakia

Dr. G.S. Lee, Korea Basic Science Institute, South Korea

Mr. Dennis Bruggink, Fusion Library, University of Wisconsin, USA

Institute for Plasma Research, University of Maryland, USA

Librarian, Fusion Energy Division, Oak Ridge National Laboratory, USA

Librarian, Institute of Fusion Studies, University of Texas, USA

Librarian, Magnetic Fusion Program, Lawrence Livermore National Laboratory, USA

Library, General Atomics, USA

Plasma Physics Group, Fusion Energy Research Program, University of California at San Diego, USA

Plasma Physics Library, Columbia University, USA

Alkesh Punjabi, Center for Fusion Research and Training, Hampton University, USA

Dr. W.M. Stacey, Fusion Research Center, Georgia Institute of Technology, USA

Dr. J ohn Willis, U.S. Department of Energy, Office of Fusion Energy Sciences, USA

Mr. Paul H. Wright, Indianapolis, Indiana, USA 
The Princeton Plasma Physics Laboratory is operated by Princeton University under contract with the U.S. Department of Energy.

\author{
Information Services \\ Princeton Plasma Physics Laboratory \\ P.O. Box 451 \\ Princeton, NJ 08543
}

Phone: 609-243-2750

Fax: 609-243-2751

e-mail: pppl_info@pppl.gov

Internet Address: http://www.pppl.gov 